\title{
The Inequity In The Current Tax System: Does The Alternative Minimum Tax Create Additional Problems In The System?
}

Constance J. Crawford, (Email: ccrawfor@ramapo.edu), Ramapo College of New Jersey Corinne L. Crawford, (Email: ccrawford@mmm.edu), Marymount Manhattan College

\begin{abstract}
Historically, the Alternative Minimum Tax was enacted to correct the inadequacies and deficiencies in the IRS tax code. Today it creates unfairness. The AMT is complex and has been recognized as the most serious problem faced by taxpayers. Could this be a consequence of bi-partisan neglect? The amount of AMT victims may double in 2006 as tax cut solutions expire. AMT will become the de-facto tax liability for the middle income taxpayer. AMT was not instituted for revenue generating purposes, but rather as a symbolic gesture denoting fairness. Unfortunately, it has created a social injustice for the working middle class.
\end{abstract}

\section{INTRODUCTION}

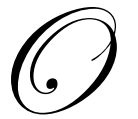

n December 8,2005 The United States House of Representatives by an overwhelming majority, 414 to 4 passed H.R. 4096, the "Stealth Tax Relief Act of 2005". Although, this bill has an intriguing name, it merely extended a one year patch to the, "complex, convoluted monster, the AMT threat to the middle class". (J. Linder, 2005). Specifically, H.R. 4096 extends the higher alternative minimum tax, (AMT), exemption levels by one year (through 2006) and indexes these amounts to reflect inflation. Without this action, the AMT exemption amounts will fall from $\$ 58,000$ to $\$ 45,000$ for married couples and from $\$ 40,250$ to $\$ 33,750$ for single individuals. According to Thomas Reynolds, the sponsor of H. R. 4096, the bill will protect 15 million people from paying the AMT in 2006.

The Senate has a similar bill pending. However, Senate Majority Leader Bill Frist announced December 14, 2005 that the Senate will not vote on this bill during the final session of 2005 . So on December 31, 2005, the temporary patch will expire leaving an additional 15 million taxpayers subject to the AMT for the first time. However, due to strong bipartisan support it is expected that the Senate will pass the bill in early 2006 and have it retroactively apply back to the expiration date. President George W. Bush is expected to sign the joint bill when it reaches his desk.

So as of December 31, 2005 the fate of 15 million taxpayers hangs in the balance. Will they be subject to the AMT or will crisis be averted for yet another year? Even more ominous is the projection of the Congressional Budget Office that 1 in 4 taxpayers will be subject to the AMT by 2010, unless a permanent fix is enacted.

\section{HISTORY OF THE ALTERNATIVE MINIMUM TAX}

The AMT originated through the minimum income tax enacted in 1969. Congress enacted the minimum tax in response to testimony by the Secretary of the Treasury, that 155 people with adjusted gross income above $\$ 200,000$ had paid no income tax on their 1967 tax returns. Congress soon realized that this was a real hot button issue, in that more people wrote to Congress to complain about the 155 people who paid no income tax than had written about the Vietnam War. (United States Congress- Joint Economic Study on the AMT, 2001). 
The original minimum tax was an add on tax of 10 percent on tax preferences. The tax was amended in 1976 when a Treasury study found that 244 taxpayers with adjusted gross income above $\$ 200,000$ were still paying no income tax. Under this amendment the tax base was broadened and the rate was raised to 15 percent. The tax was amended again in 1978, 1986, 1990 and finally to its present incarnation in 1993. According to Congress the goal of the AMT is to make everyone with significant income pay some federal income tax. (Joint Economic Study, 2001)

Until recently, when the AMT began affecting more middle- income taxpayers the amount of revenue it raised was quite small. "Fundamentally, the AMT was not about revenue but about symbolism-the resentment of many taxpayers at a few people with high incomes paying no income tax. "(Joint Economic Study, 2001). Kurt Schuler the Senior Economist to the Chairman of the United States Congress-Joint Economic Study of the AMT concluded the study as follows:

"After having tried and failed for more than 30 years to make everyone with high income pay some income tax, it has become apparent that the tactics chosen have not worked. In a tax code as complex as ours, there are always opportunities for a few high-income people to reduce their liability to zero. . . The AMT was enacted as an attempt to target the rich but has become a tax on parts of the middle class. If nothing is done to reform the AMT, it will eventually become the dominant type of income tax. If taxpayers and Congress could have foreseen in 1969 how the minimum tax would turn out, it is doubtful they would have approved it."

\section{CURRENT PROBLEMS WITH THE CALCULATIONS OF THE AMT}

Congressman John Linder, the co-sponsor of H. R. 4096 has stated, "The AMT is a case study of our chaotic code- it forces Americans to perform two tax calculations using two completely different sets of rules, ..... Under current law taxpayers must calculate their regular tax and the AMT, and pay whichever amount is higher. The problem is that the AMT is calculated with a completely different set of highly complex rules. The Urban-Brookings Tax Policy Center stated in 2004 that the AMT "is notoriously and pointlessly complex". (Urban Institute, Brookings Institution, 2004). The Internal Revenue Service has estimated that it takes 13 hours to prepare a regular tax return without schedules and an additional 6 hours to comply with the AMT rules. (Internal Revenue Service, Statistics of Income Bulletin, Fall2000).

The regular tax has been indexed for inflation since 1985. The AMT is not indexed for inflation. Thus, it ensnares more and more taxpayers each year. The Congress has mitigated the problem to some extent with its periodic patches. However, the Joint Economic Study of 2001 found that the periodic Congressional increases have not kept pace with inflation. (Joint Economic Study, 2001). The Bush tax cuts have exacerbated the problem. The Urban -Brookings Tax policy Center concluded in their 2004 study on the AMT, that, "If the AMT had been indexed when the regular tax was and had the 2001 tax cut had not been enacted only 300,000 households would face the AMT in 2010." (Urban Institute, 2004). Under the current law the Institute projects the AMT will affect 33 million taxpayers one-third of all tax returns, in 2010. (Urban Institute, 2004).

The Urban-Brookings Institute has found that the AMT is "poorly targeted" an "imposes penalties on marriage and having Children". (Urban Institute, 2004). According to the Institute a fundamental problem with the AMT is that it gives preferential treatment to capital gains which are the lynch pin of most tax shelters, the instrument the AMT was originally trying to eliminate. (Urban Institute, 2004). The AMT prohibits exemptions for dependents; because of this couples will be more than 20 times as likely as singles to face the AMT in 2010. (Urban Institute, 2004). The AMT also disallows deductions for state and local taxes, property tax; home equity loan interest and child care tax credits. These are the deductions that are probably the most valuable to middle class families with children. Additionally, the disallowance of state and local taxes and property tax disproportionately affects people on the east and west coasts.

\section{OPTIONS FOR AMENDING THE AMT}

Although, most public policy officials agree that the AMT is in need of adjustment, the recommendations for reform range from minor adjustments to a complete repeal. 
The United States Congress Joint Economic Committee Study on the AMT came up with five options for dealing with the AMT. The first option is to do nothing. Thus, the AMT will become a defacto flat tax by 2010 . The second option is to alter the AMT to reduce the burden on middle-class families. Under this option exemptions for dependents and the standard deduction would be allowed. The third option is to index the AMT for inflation. This option would slow the growth in the number of people affected by the AMT, but ultimately would not prevent the AMT from affecting more and more taxpayers. The fourth option would be to allow for more deductions in the calculation of the AMT. For example the deduction for state and local taxes could be allowed. By allowing for more deductions the AMT would become more like the regular tax. The final option is to repeal the AMT completely. This option would phase out the AMT over several years and completely eliminate it eventually. (Joint Economic Committee Study, 2001).

The Urban-Brookings Tax Policy Center has also drafted some options for reform of the AMT. The Center suggests that the AMT be amended to allow for dependent exemptions and the inclusion of personal credits against the AMT. Another approach the Center suggests is to retarget the AMT at high income tax avoiders by treating the lower tax rates on capital gains and dividends as preference items. (The Urban Institute, 2004).

\section{CONCLUSION}

The history of the AMT reinforces the need for society to reflect on "unintended" consequences imposed by an inequitable tax system. AMT was initially mandated to prevent an extremely small number of affluent taxpayers from paying no income tax. This amounted to a symbolic attempt to close loopholes designed for the wealthy. Unfortunately, there still exists today, some wealthy members of society who still do not pay any income tax. The AMT has not fixed the problem, but instead has created a nightmare of confusion and increased the complexity of an already problematic tax system.

Congressman John Linder the co-sponsor of H. R. 4096 has stated, "I continue to believe that fundamental tax reform must be part of the Congressional agenda in 2006. The AMT is just a symptom of a twisted tax code that is now so broken that it routinely results in these unintended tax consequences and undermines hardworking American workers everyday. It is time to scrap the crippling code and move to a system that is fair to all Americans." If the AMT is not amended studies from Congress and other prestigious institutions estimate that between 20 and 30 percent of all taxpayers will be paying the AMT by 2010.

The AMT is an overly complex system that is not achieving the goal it was created for, making sure that all high-income individuals pay some federal income tax. Instead it is putting an undue compliance burden on all taxpayers, and many would argue an unfair tax on middle-class families on the east and west coasts. It is clear there is a problem with the AMT, but what remains unclear is how to fix it. Kurt Shuler, Senior Economist to the Chairman of the Joint Economic Committee Study on the AMT encapsulated the difficulty of the AMT problem in the following statement:

"It may not be politically possible to achieve a system so simple and with so few deductions, exemptions and tax credits that everyone with income above a certain level pays federal income tax. If not, Congress and the American people will confront again one of the fundamental questions about taxes: to what extent are they primarily a means of raising revenue in the most economical way, and to what extent should they be a tool of social engineering? The Congress that enacted and amended the minimum tax and later the AMT placed a high value on trying to make everyone with high income pay federal income tax, rather than accepting a simpler system that would allow a few high income people (as well as many middle and low-income ones), to pay no tax. The AMT has now grown so big and complex that it is becoming a tax on the middleclass. The quest to catch an additional few big fish in the tax net has enmeshed hundreds of thousands, even millions, of small fish."

\section{FURTHER RESEARCH INITIATIVES}

According to the House Ways and Means Commission if the AMT were eliminated it would cost the Treasury 600 billion over 10 years. (Joint Committee Study, 2001). As the AMT has become such a large revenue 
generator all changes to its implementation will be thoroughly studied and debated by Congress. We will continue to track all legislative iniatives and summarize the results in future research papers.

\section{REFERENCES}

1. Andrews, E. (2005). Hmmm. What's This Alternative Tax? Hey, Wait! Ouch! The New York Times. Dec. 4,2005

2. Andrews, E. (2005). House Approves Tax-Break Packages. The New York Times, Dec 8, 2005. Retrieved from http://www.startribune.com

3. Bartlett, B. (2000). Repeal the AMT. National Center for Policy Analysis, Jan. 31, 2000. Retrieved from://www.ncpa.org

4. Benner, K. (2005). Alternative Minimum Tax 101. CNN Money, Nov. 10, 2005. Retrieved from http://cnnmoney.printthisclickability.com

5. Blumner, R. (2005). The Republicans Millionaire Relief Act. St. Petersburg Times. Dec. 2005. Retrieved from http://www.sptimes.com/2005/12/05/news

6. Burman, L., Gale, W., etal. (2004) The Individual Alternative Minimum Ta: A Data Update. Aug. 30, 2004. Retrieved from http://www.feedback @ taxpolicycenter.org.

7. Chaddock, G. (2005). Tax-cut MomentumWaning. ABC News, Dec. 8, 2005. Retrieved from http://abcnewsgo.com

8. Deibel, M. (2005). Tax Cuts in Jeopardy this Holiday Season. Scripps Howard News Service, Dec. 2, 2005. Retrieved from://www.sitnews.us

9. Dodge, C. and Donmoyer, R. (2005). Congresses $\$ 70$ Billion Tax Cut Pits Rich against Super-rich. Bloomberg.com, Dec 5, 2005. Retrieved from http://www.bloomberg.com

10. Hall, K. and Kuhnhenn, J. (2005). House Extends Exemption Levels for Alternative Minimum Tax. Dec. 7, 2005. Retrieved from http://www.mercurynew.com

11. Horney, J. (2005). Repealing the AMT Without Offsetting The Cost Would Add \$1.2 Trillion to the Federal Debt Over the Next Decade. Center on Budget and Policy Priorities, June 9, 2005. Retrieved from http://www.chpp.org

12. Hubbard, R. and Reich, R. (2005). Guns, Butter and Retired Boomers: How Do We Pay For It All? The Wall Street Journal, Nov. 29, 2005. Retrieved from http://online.wsj.com

13. Hulse, C. (2005). Divisions Over Money Await Congress in Year-End Push. The New York Times, Dec. 6, 2005. Retrieved from http://www.nytimes.com/2005/12/06

14. Orszag, P. and Pechman, J. (2004). The Federal Budget Outlook. Feb. 3, 2004. The Brookings Institution, Tax Policy Center.

15. Reynolds, T. (2005). H.R. 4096. To Amend IRC of 1986 to Extend to 2006 the Alternative Minimum Tax Relief...GovTrack. Us, Oct. 20, 2005. Retrieved from http://www.govtrack.us/congress/billtext.xpd

16. Roberts, T. (2005). Stealth Tax Relief Act Passes. Community News, Dec. 8, 2005. Retrieved from http://community.emeraldcoast.com

17. Saxton, J. (2005). The Alternative Minimum Tax for Individuals: A Growing Burden. Joint Economic Study, May 2001. Retrieved from http://www.house.gov/jec/tax/amt.htm

18. Turner, D. (2005). Reynolds Gets Wide Support for Bill Limiting AMT. The Buffalo News, Dec. 8, 2005. Retrieved from http://www.buffalonews.com

19. Wendland, J. (2005). It's Time for Fair Taxes, not GOP Pandering to the Ultra Rich. Political Affairs Magazine, Dec. 8, 2005. Retrieved from http://www.political affairs.net 